\title{
Holding up the mirror: the impact of strategic procurement practices on account management
}

\begin{tabular}{|l|l|}
\hline Dr Lynette J. Ryals & Beth Rogers \\
Senior Lecturer in Marketing & Senior Lecturer \\
Cranfield School of Management & Portsmouth Business School \\
Cranfield & Richmond Building \\
Beds & Portland Street \\
MK43 0AL & Portsmouth PO1 3DE \\
& Tel: 02392 844600 \\
Tel: 01234751122* & Fax: 02392844037 \\
Fax: 01234751806 & Beth.rogers@port.ac.uk \\
\hline Lynette.ryals@cranfield.ac.uk & \\
\hline
\end{tabular}

* Lead author for correspondence

Accepted for publication by: Business Horizons 


\section{Holding up the mirror: the impact of strategic procurement practices on account management}

Procurement has grown up. It is now a strategic business function that increasingly recognizes the importance of strategic supplier relationships, the mirror image of key account management. It is time to assess the impact of this shift on the profession and practice of account management. This paper examines customer adoption of strategic procurement and then discusses the implications this has for account managers at the suppliers serving these customers. New techniques are emerging in these special relationships, including the use of psychological contracts and comeasurement and monitoring. Perceived fairness will also have a major impact on the customer's view of their suppliers. Account managers must recognize these changes or fall victim to supplier delusion, the belief that they are performing better than they really are.

Key words: Procurement; key account management; supply chain relationships

Procurement is big business. A company's purchases of goods and services can account for $50-70 \%$ of total costs (Mcginnis \& McCarty, 1998) and form $70-80 \%$ of the cost of new products in some industries (Minahan \& Vigoroso, 2002). Coupling the scale of procurement costs with a recent increasing trend for 
outsourcing entire processes, it is hardly surprising that the purchasing profession is becoming more strategic. In many companies, strategic procurement is now seen as key to competitiveness and Carr \& Pearson (2002) find that it has a positive effect on the firm's financial performance.

Traditional purchasing is driven by the desire to cut costs of purchase and shortterm profit improvement, historically often resulting in supplier proliferation, transactional rather than relationship behavior, and emphasis on price reduction. Strategic procurement, by contrast, looks at how the purchasing of goods and services, including outsourcing of entire processes, can deliver better long-term shareholder value. Strategic procurement is a very different approach which involves reducing the supplier base, co-operative negotiation with suppliers, quality interaction with suppliers, and developing long-term relationships with the best suppliers. Nevertheless, these strategic procurement behaviors are linked to better company performance (Swinder \& Seshadri, 2001).

The process of developing key supplier relationships is the mirror side of Key Account Management. It is now well understood that long-term relationships can pay off for both customers and suppliers. However, this means abandoning traditional adversarial roles and recognizing that more can be achieved from world-class suppliers if a company behaves like a world-class customer (Morgan, 1998). In turn, this means offering commitment and having a "can-do" approach, such as helping suppliers secure finance by agreeing long-term contracts and work-in-process payments. Just as the key account manager is a boundary spanner (McDonald, Rogers \& Woodburn, 2000) for the supplier, so is the purchasing and supply manager for the customer organization. Strategic 
procurement managers are now just as committed as key account managers to identifying mutual gain from a key supplier / key customer relationship.

Assumptions about the nature of supplier-customer relationships have changed over the past decade. Suspicious win/lose scenarios are out. The current thinking is that buyers and suppliers can have common goals; that there is no need for customers to have total control; and that transactions are not random and episodic. An example of strategic procurement thinking is provided by Kodak, who developed a successful supplier partnership program based on careful supplier selection and relationship measurement and management (Ellram \& Edis, 1996). Kodak obtained benefits through lower costs and reduced cycle times and gained improved solutions through earlier supplier involvement. Suppliers benefited from a greater share of Kodak's business and secure longterm demand from the customer; they also gained competitive strength.

Strategically-minded procurement managers recognize that supplier partnerships are patterns of purposeful behavior that can deliver value to both parties. This new mindset from a traditionally price-driven adversary represents an opportunity for suppliers who have key account management capabilities and the ability to respond. However, there are still underlying supplier-customer mismatches to be addressed. For procurement managers, there are two issues in moving towards strategic procurement: how they measure supplier performance; and the risk of increasing their dependence upon a smaller number of suppliers. For account managers, an important implication of closer relationships with fewer, larger customers is the need for greater proactivity and openness in performance measurement. Second, account managers need a better 
understanding of key customer profitability and the payback on the relationship because suppliers, too, encounter risks in dealing with fewer, larger customers. Customer profitability risks have been extensively discussed elsewhere and will not be examined here. Our theme is the additional issues that are generated when a major customer moves towards strategic procurement. These are the problems of co-measuring a complex business relationship to minimize the risk inherent to the customer in supplier dependence.

\section{The mirror image: measurement and risk affect both suppliers and customers}

The risk of dependence impacts both parties to a relationship. Purchasing decision-makers have concerns about dependence on a single source for a key product or service, but sales managers also need to manage the risk of overdependence on a few strategic customers. Working together in strategic supplier/customer relationships requires a grasp by both parties of some new tools and ways of working together. In particular, the co-measurement and discussion of performance including the development of trust and both parties' perceptions of fairness is essential to the sustainability of mutual benefit from the relationship. 


\section{The mirror cracked, or Why your customers might walk}

\section{away}

Supplier selection is as strategic to purchasing as customer portfolio analysis is to sales management. Just as key account managers focus on understanding customers' business needs, purchasers work to understand supplier capabilities. They do this in order to work with the best. Purchasers bear a considerable risk management responsibility on behalf of the firm, balancing the trade-off between control (usually associated with playing a number of suppliers off each other) and dependence (single-sourcing). They need to protect the firm from quality mishaps, service deficiencies, and cost over-runs. They have to judge the risk of supplier failure, and keep up with suppliers' financial health.

Supplier reduction has been a popular purchasing strategy since the 1980 s. Poor performers are dropped, but purchasers see a vested interest in helping their best suppliers to survive and thrive. There are many reasons why customers may move towards single sourcing or supplier concentration, including the need to increase co-ordination in a complex task or process; buffering the firm against technological uncertainty; and protecting the firm against skill scarcity. Other customers justify supplier concentration through asset efficiency, cost efficiency, better customer service, market advantage and profit stability or growth. Which supplier they select is also influenced by the emotional elements of trust and 
friendship (Figure 1). Essentially, savvy customers now want their key suppliers to behave differently.

\section{[Insert Figure 1 here]}

Single sourcing or supplier concentration, however, creates vulnerability. For example, the mighty Toyota product line stopped for over a day when a supplier had a factory fire (Bensaou \& Anderson, 1999) and on $6^{\text {th }}$ November 2004 the Financial Times reported that Honda had to stop its production line for two days because an earthquake disrupted component deliveries from supplier Nippon Seiki. This is an example of 'lock-in', where single sourcing of certain components makes the customer vulnerable to the supplier's risk.

In managing the trade-off between lock-in and the opportunity for performance improvement through partnership, it is difficult for the purchaser to judge who to trust. Promises of credible commitments such as partnership-specific investments are a source of advantage, but also a barrier to exit. Nevertheless, Johnson argues that the dependence of a customer on a supplier can have positive outcomes where both sides are flexible, the relationship seems durable and there is a focus on mutual financial gain. Her research indicates that the right type of relationship delivers benefits regardless of external risk levels. Being 'in it together' can be an 'uncertainty absorption mechanism' (Johnson, 1999). 


\section{Holding up the mirror: Changes in supplier performance measurement}

Once strategic suppliers have been chosen, purchasers are anxious to avoid them getting complacent. Traditionally, the challenge in purchasing has been to measure supplier performance at all. Whilst $70 \%$ of companies surveyed by the Aberdeen Group in 2002 regarded supplier performance measurement as "very important" or "critical", only half had procedures and typically they were applied to less than half the supply base (Minahan \& Vigoroso, 2002).

Yet, there is plenty of evidence that, from the customer's point of view, supplier performance measurement (SPM) works. The Supplier Performance Measurement Benchmarking Report from Aberdeen Group in 2002 found that supplier performance improves $26.6 \%$ when measured. The hard dollar savings are in the area of quality, price, on-time delivery, lower lead times, contract compliance and responsiveness (Minahan \& Vigoroso, 2002).

Measurement needs to pay off because it requires investment, such as the realtime update of the measurement system from legacy applications. Increasingly, customers demand not just conformance to certain fixed performance measures but also continuous improvement in supplier performance. The on-going challenge is to have a system sophisticated enough to identify hidden costs that can be eliminated. Negotiating a $5 \%$ price decrease for a widget is not as 
effective as larger savings that can be identified through a total cost of ownership approach.

There is also emerging evidence of a switch towards joint and shared performance measurement between strategic suppliers and their key customers. We will discuss the advantages of co-monitoring later in this paper, but first we briefly consider what traditional measurement systems comprise.

\section{How strategic procurement managers measure supplier performance}

Core transactional measures. Vendor analysis systems are not new and the core of any SPM system focuses on three key elements of "value for money" which can be easily measured per transaction. They are price, quality conformance and delivery reliability. The latter two are particularly critical to companies committed to just-in-time manufacturing because, without quality conformance and delivery reliability on the part of suppliers, production lines can stop.

Other observers argue that quality is the most important of the three core transactional measures, but that it is delivery that needs most improvement. In one case study, penalties are charged by the customer for late delivery or parts rejected (Carbone, 2004). Unfortunately, even at this apparently objective level of measurement, misunderstandings can arise. For example, suppliers can 
assume that a part-delivery is conforming to customer requirements because it is on time, although incomplete; whereas the customer treats the order as unfulfilled until complete.

As such examples demonstrate, for any one buying company the three core transactional elements may vary in importance. For example, logistics decisionmakers are likely to demand an in-depth analysis of quality, because the customer service capabilities of a contractor are more important than cost. However, it is clear that there are contradictions and trade-offs in this triad of core transactional elements. For certain kinds of customer or situation, quality or early delivery may command a higher price for the supplier. One of the developments in strategic approaches to procurement is the use by some sophisticated customers of multi-objective programming decision support systems to work out the balance they want to achieve.

Transaction-related satisfaction is essentially a 'hygiene factor', although it may lead to high perceptions of supplier quality. For example, Dow Corning launched a sub-branded e-channel in 2002 for its cost-conscious customers call Xiameter. Offering standard quantities, qualities and lead times, customer who wanted a basic package could order just that (Gary, 2005). However, suppliers should note that quality perceptions are also affected by relative performance compared to competitors, the level of customer involvement in, or knowledge of, the product/service type, and changing expectations of "standard" quality over time. Increasingly, customers are demanding not just core transaction excellence, but also service excellence from their suppliers. The Xiameter model assumed that customers who opted for it had their own chemical engineers to apply the 
product; yet many companies during the 1990s downsized their own expertise in favor of supplier expertise.

Service. Research shows that, close on the heels of the core transactional measures in buyers' requirements, was responsiveness. In fact, companies studied by Billesbach, Harrison \& Croom-Morgan (1991) rated response flexibility higher than price. Responsiveness is one of the main areas in which account managers can enhance customer satisfaction, who are often seen as a single point of contact for key buying decision-makers. This perception of responsiveness is the first subjective measure to appear in the 'balanced scorecard' used by strategic procurement managers. The more sophisticated ones have even developed measures of responsiveness, such as time to answer phone calls but, in many cases, it is likely that it is the subjective views of the procurement manager that are recorded.

Service also encompasses technical support. The importance of technical support is dependent on the type of product/service bought and the skills level of the buying firm. Although overall technical support was allocated medium importance in the Billesbach study, it is high for some companies and product types. The scope of support can also be important, as some companies may require technical support to a wide geographical spread of branches. Performance guarantees for problem resolution are increasingly expected, and suppliers can easily be measured against these.

The shift towards customer problem resolution is the mirror side of solutions selling. The past ten years has seen a shift towards solution selling. On the 
customer side, there have also been signs of change. Krause \& Ellram (1997) reported research results indicating that customers who committed to pro-active and long-term supplier development, including high levels of communication, continuous improvement of processes between the firms and investment in improved operations enjoyed better overall performance from their suppliers. Other authors (Kneymeyer et al, 2003; Fisher, 2004) have noticed how these factors are being monitored. Their relevance to purchasing professionals appears to be increasing. Despite the difficulties of measuring intangible and subjective factors, broader measures are now used on supplier scorecards

Process-based. Most companies will be concerned with a supplier's safety record, and be keen to see evidence that safety is built into their processes as well as products. But, beyond this hygiene factor, buying decision-makers are increasingly looking for process innovation from suppliers, either through offering turnkey services, such as flexible logistics or vendor-managed inventory (the supplier takes responsibility for the customer's stock management), problemsolving and trouble-shooting cross-boundary processes to reduce errors. McDonald et al (1995), observed a number of examples, most notably the success of a logistics company (supplier) working with a mail order company (customer). Both parties collaborated in continuously mapping their crossboundary processes to identify efficiency improvements and cost savings. The savings were invested in co-branding the streamlined service to end customers.

Company-based. Although primarily considered at supplier selection stage, buying decision-makers know that they have to keep abreast of the corporate health of their suppliers. Ellram's research suggests that cultural 
compatibility, long term plans, financial stability and technological capability should be periodically checked (Ellram, 1991). For example, Global Healthcare Exchange $(\mathrm{GHX})$ is an electronic market place set up by medical supply companies to serve the US and now the UK healthcare market. It aims to replace a plethora of systems and provide a cheaper and more effective approach. GHX has proved attractive to UK hospitals not only because of its US track record and perceived financial and technological strength, but also because its key founding concepts of neutrality, confidentiality, equality and efficiency appeal to UK hospitals operating under National Health Service principles (Mouncey, McDonald \& Ryals, 2004).

Communications. All commentators on the success of supplier/buyer relationships agree that "profusion" of communication is absolutely critical. As with key account management, purchasing academics note the need for a parallel relationship structure, in other words, communication between firms at all points of contact. Fisher (2004) gives an outstanding best practice example of Nortel's 'customer fulfillment network', a web-based portal to add intelligence to the supply chain by enabling communications between all players, not just two.

Communication can be evaluated and measured at many levels. The quality of transacting information, which may include layout of invoices, is one thing. Interorganizational systems that exchange and integrate information to support decision-making can reduce costs and enhance market responsiveness. 
However, measurement is also made on the judgment of interpersonal skills. Is the supplier pro-active? Can the supplier's representative negotiate and renegotiate when the unforeseen happens? Can supplier and buyer share information, acknowledge each other's perspective, exchange resources, offer support, and have an open discussion utilizing high quality reasoning? Is each expert in the decision-making unit matched with an expert in the supplier?

Relationship. Research with buying decision-makers makes clear that satisfactory performance on hygiene factors does not necessarily lead to loyalty to a supplier. However, relationship quality is correlated with customer retention. Thus, good customer relationships pay off. Successive reports and books by McDonald et al. (1995; 1999; 2000) note the importance of suppliers gaining a deep understanding of the customer's strategy and planning to contribute to the customer's achievement of it. Best practice suppliers invest time and money in their key relationships, creating a 'spiral' of positive results for both parties.

A customer also needs to be confident that the supplier will not act opportunistically. Commitment is key; it is about working at developing the relationship and 'resisting the short-term' (Kneymeyer, Corsi \& Murphy, 2003). Suppliers can demonstrate their commitment to a customer by offering additional services that will contribute to the development of a mutually beneficial partnership. In other studies, customers have expressed admiration for suppliers who share ideas and initiatives and improve processes capabilities to match customer needs. Customers expect suppliers to identify with their goals and anticipate future needs. With these factors in place, trust can build. 
Investment. Once a supplier is trusted as a partner, the relationship with the customer usually moves towards joint investments, such as jointly managing assets used in the relationship (machinery, vehicles, etc.). The most valuable form of co-operation is the early involvement of suppliers in new product design and development, which has been shown to deliver significant quality improvements that feed throughout the supply chain to the end-consumer. Lucent bring in their strategic suppliers at the design phase of new products. This means that they can influence architecture and analyze the impact of new product concepts on their own costs, which helps Lucent to design costs out of new products (Carbone, 2002). When organizational commitment reaches these levels, measurement is needed to monitor trust and the quality of the relationship. The implications for account managers are explored in the following section.

\section{Looking In the Mirror: What Does This Mean For}

\section{Account Managers?}

Supplier performance measurement from the customer side is changing as strategic procurement becomes more of a force in supplier/ customer relationships. Meanwhile, what are suppliers measuring about their performance with customers? Increased customer sophistication on the procurement side needs to be met with increased effectiveness not just in delivering customer service but in being seen to do so. 


\section{How suppliers assess their own performance}

The history of success with customers for many decades was linked primarily to sales volume. Bigger was better. Customer revenues were easy to measure, and salespeople were paid on them. In recent years, more measures are in use such as order size, repeatability, standardization, timeliness of orders (coming in), pricing terms, price structure, accuracy of specifications, schedule for delivery, and credit taken. Ultimately the supplier is looking for indicators of customer profitability, which is notoriously difficult to measure. However, customer profitability analysis is now recognized as a vital measure for marketing, especially as analysis of relationships between suppliers and their key customers shows that they do not pay off for suppliers unless carefully managed.

Most companies try to have some measure of customer satisfaction as well. This needs to be measured objectively, as salesperson or account manager feedback is notoriously bad as an indicator of customer satisfaction. Unfortunately for suppliers, the results from satisfaction surveys seem to be of limited usefulness. Customers tend to give overly flattering reports about their suppliers; most customer satisfaction surveys show bias towards the top two satisfaction ratings (excellent and good). Still worse, satisfaction is a poor indicator of repurchase; customer loyalty is only $75 \%$ even at the highest levels of satisfaction (Sharma, 1997; 2000). 
Ultimately, what the customer perceives is the only indicator of success and repurchase. Therefore, smart account managers will discuss with their key customers what it is that the customer actually measures about the supplier's performance. The good news: strategic purchasers are willing to share their views and the data on which they are based.

\section{Through the looking glass: Emerging evaluation techniques in key relationships}

New techniques are emerging in close relationships between suppliers and their sophisticated key accounts. Where strategic procurement is concerned, this is no longer an adversarial, zero-sum relationship. It is no longer 'we win, the other side loses'. Instead, the name of the new game is working together on shared measurement and on joint initiatives to reduce the costs or improve business efficiency on both sides. New concepts include psychological contracts and fairness, as well as co-monitoring of the relationship by both parties.

\section{Psychological contracts and perceptions of fairness}

The goal of strategic purchasers is not to beat up suppliers, but to get them to be easy to work with. Being "easy to do business with" has long been known as a critical success factor for key account strategy (McDonald, Millman \& Rogers, 1995). It is recognized that there is a need to give suppliers an understanding of 
required performance, the consequences of failure, and to offer rewards for excellence. Thus, customers need to ensure transparency on bids and schedules, set accurate and timely specifications, and give clear evaluation of supplier performance.

Blancero \& Ellram (1997) look at the psychological contract between the decision-makers in both organizations. Psychological contracts are not the formal, written contracts that are usually put in place where one or both parties wants to clarify what happens if the relationship breaks down. Formal contracts tend to deal with penalties, guarantees and litigation. By contrast, psychological contracts are about the positive expectations of the relationship and perceptions of reciprocity. Clarifying the views about what is expected out of the relationship on both sides can help avoid issues of perceived unfairness. Perception is not always accurate. Buyers perceive that they meet top supplier managers more often than they do, and that they give more information to them than they do! Buyers think that they do more relationship building than suppliers think they do. And suppliers think that they fulfill their contractual obligations better than they do.

As in other strategic business relationships, the principle of organizational justice comes into play - can both parties believe that judgment is fair? Psychological contracts can be violated, because expectations change or are not met, although the violator is not always aware that the violation has taken place. In fact, blatant violation is rare. The cause of the violation may be a misunderstanding (perhaps arising from complacency) or disruption caused by an external event. McDonald, Millman \& Rogers found that "breach of trust" was the primary cause 
for customers to disengage with suppliers, and the purchasing decision-makers interviewed could cite apparently tangible examples such as missed deliveries or lack of support. Nevertheless, as noted earlier, even tangible events give rise to alternative interpretations, so how can the existence of trust or lack of it be measured? Both parties must be prepared to share their perceptions frequently - formally as well as informally.

Do supplier and customer decision-makers meet to resolve problems, or does the customer just strike the supplier off the list? Suppliers will perceive fairness if there is a process and procedure to resolve disputes which is consistent, accurate and ethical. Fairness encourages companies to behave well. Blancero \& Ellram conclude that fairness involves both parties assessing and exchanging information, sharing benefits, a degree of personal sensitivity and maintaining belief in the on-going relationship. Humphries \& Wilding (2004) demonstrate that soft factors such as co-operation, co-ordination and collaboration can be measured from the perspective of the buyer and of the seller in supply chain relationships. The resulting analysis enables both parties to share perceptions of their relationship.

\section{A model for co-monitoring of strategic relationships}

A critical aspect of supplier/customer trust that the authors have noted from experience with Cranfield's Key Account Management Best Practice Club is both parties discussing and agreeing the nature of their relationship and whether or 
not there is potential for further development. In the model illustrated in Table 1 , we have used a hierarchy of supplier/customer relationships to set a framework for analyzing current position and potential and co-monitoring of relevant performance categories. This model draws upon earlier relational development models (Millman \& Wilson, 1994) as well as Maslow's hierarchy of needs, which we see as analogous to the hierarchy of needs of those managing supplier/customer relationships. This simple model is designed to facilitate initial dialogue between suppliers and customers. Suppliers and customer may design their own checklists and agendas for regular and on-going dialogue or use industry standards. For example, the UK Ministry of Defence encourages the use of the "Supply Chain Relationships In Aerospace" (SCRIA) program for its supply chain (Lamming \& Cousins, 1999). SCRIA, which enables strategic partnering throughout the UK defense industry, has been in operation for seven years. Nearly all prime defense contractors are participating to achieve savings and efficiencies throughout the aerospace supply chain. The overall aim is to make the supply chain lean. Measurement is a key element; it is perceived that 'blame' approaches add cost and that collaborative measurement and risk sharing reduce operational, managerial and strategic costs. SCRIA obviously has the advantage of a very powerful end-customer driving co-operation throughout the supply chain.

\section{[Insert Table 1 here]}

A supplier and customer may work successfully together for many years at the 'basic' level, provided that the customer's expectations of price, quality and delivery performance are understood and met by the supplier. Suppliers of non- 
critical products such as office supplies may never be monitored beyond this level, although a performance review of the actual and psychological contracts is still occasionally necessary to ensure that the supplier sustains competitiveness and does not become complacent.

Complacency on the part of the incumbent supplier is perhaps the biggest risk to the concept of partnering and procurement directors are well aware of the danger. Roger Whittier, Director of Purchasing, Intel Corp, quoted on www.purchasing.com, commented "complacency does creep in if you do not carefully watch it. External benchmarking and occasional testing of the waters by utilizing competition is required. If you do not do this, in the end your supplier will become uncompetitive and then you will slowly also lose your competitive advantage."

Where the relationship is 'integrated' and a substantial service, support and communications element is involved, more subjectivity in performance appraisal is inevitable. For example in the implementation of IT applications, line managers or technicians may not be aware of the depth of users' frustrations. Both parties should monitor these categories, and if either has technology that records contacts automatically (e.g. call management) that information should be shared. Feelings about the quality of call handlers' listening skills or engineers' dedication are not so easy to capture. Discussions of expectations and perceptions should occur at least monthly, and with a wide group of decision-makers and influencers. 
'Interdependence' is normally accompanied by efforts to improve cross-boundary processes and monitor the overall quality of the relationship. It is often at this stage that customers in particular look for an exchange of ideas as well as information and data. Customers who invest time in supplier development in return for their key account status expect closeness to result in additional tangible benefits, although these will be more difficult to measure. For example, avoidance of hidden costs from improving to robustness a process that had been breaking down can often only be estimated. The detail involved in supplier and customer personnel working together at many levels should ensure frequent checking of perceptions of fairness. Nevertheless, the key account manager and key purchasing decision-maker should be consistently gathering and comparing feedback.

Some practitioners have commented to the authors that the only truly transparent supplier/customer partnership is a joint venture. Although not always formalized as a JV, some supplier/customer relationships do involve the integration of functions. Integration involves significant risk for both parties and therefore requires formal planning and monitoring of return on investment. Since the value of any arrangement will change over time and the focus of either party may drift, pro-active monitoring of perceptions of trust and fairness is still advisable. Supplier/customer relationships are commercial, not personal, and a mutually agreeable exit strategy will be part of their trustworthiness. 


\section{Key account managers, please note...}

For some time now, it has been known that supplier performance management provides benefits for the customer organization. However, in an era of developing strategic procurement, different measures of the relationship are becoming appropriate and more sophisticated systems can be instrumental in tracking the benefits of supplier/customer partnerships. Continuous tracking is now vital, as strategic customers now demand not just a high level of performance but also continuous improvement. Smart account managers are beginning to understand that openness with customers, exchanging performance data and even comonitoring may identify further efficiencies and cost-savings as cross-boundary processes and relationship quality are examined.

\section{... you may be suffering from supplier delusion}

Buying decision makers - strategic procurement directors - have said that they still perceive 'supplier delusion' to be a problem. This is where the supplier thinks it is performing better than it really is, in the customer's view. To be truly successful at relationship management and customer retention, account managers must take supplier performance measurement very seriously. Engaging cross-boundary measurement and discussion of measurement should be very beneficial to relationship-building. 


\section{References}

Bensaou, B. M. and Anderson, E. (1999). Buyer-supplier relations in industrial markets: When do buyers risk making idiosyncratic investments? Organizational Science, 10 (4) Jul-Aug 1999, 460-481.

Blancero, D. and Ellram, L. M. (1997). Strategic supplier partnering: a psychological perspective. International Journal of Physical Distribution and Logistics, 27 (9-10), 616-629.

Billesbach, T. J., Harrison, A. and Croom-Morgan, S. (1991). Supplier Performance Measures and Practice in JIT companies in the US and the UK. International Journal of Purchasing and Materials Management, 27 (4), 2428 Fall.

Carbone, J. (2002). Lucent's supply chain focus fattens margins. Purchasing magazine online, 19th September 2002. Accessed 25th March 2005 from www.purchasing.com

Carbone, J. (2004). Using TCO to rate suppliers. Purchasing, February $19^{\text {th }} 2004$, 30-34.

Carr, A. S. and Pearson, J. N. (2002). The impact of purchasing and supplier involvement on strategic purchasing and its impact on firm's performance. International Journal of Operations and Production Management. 22 (910), 1032-1053.

Ellram, L. M. (1991). A managerial guideline for the development and implementation of purchasing partnerships. International Journal of Purchasing and Materials Management, 27 (3), Summer, 2-8.

Ellram, L. M. and Edis, O. R. V. (1996). A case study of successful partnering implementation. International Journal of Purchasing and Materials Management, 32 (4), Fall, 20-28.

Fisher, L. M. (2004). From vertical to virtual. strategy+business, 22, case study reprint downloaded 14 May 04 from www.bah.com.

Gary, L. (2005). Dow Corning's Big Pricing Gamble. HBS Working Knowledge, March 7th 2005, accessed March 25th 2005.

Humphries, A. and Wilding, R. (2004). Sustained Monopolistic Business Relationships: A UK Defense Procurement Case. European Journal of Marketing, 38 (1-2), 99-110.

Johnson, J. L. (1999). Strategic integration in industrial distribution channels: managing the interfirm relationship as a strategic asset. Academy of Marketing Science, 27 (1), Winter, 4-18. 
Knemeyer, A. M., Corsi, T. M. and Murphy, P. R. (2003). Logistics outsourcing relationships: customer perspectives. Journal of Business Logistics, 24 (1), 77-109.

Krause, D. R. and Ellram, L. M. (1997). Success factors in supplier development. International Journal of Physical Distribution \& Logistics Management, 27 (1-2), 39-53.

Lamming, R. and Cousins, P. (1999). For richer or poorer. Supply Management, April $15^{\text {th }}, 26$.

McDonald, M., Millman, A. and Rogers, B. (1995). Key Account Management learning from supplier and customer perspectives Cranfield School of Management: Report by the Key Account Management Best Practice Research Club.

McDonald, M., Rogers, B and Woodburn, D. (2000). Key customers - how to manage them profitably. Oxford: Butterworth Heinemann.

McDonald, M. and Woodburn, D. (1999). Key Account Management - building on supplier and buyer perspectives. Cranfield: Cranfield School of Management / Financial Times research report series.

McGinnis, F. and McCarty, L. (1998). Strategic account management in the new procurement environment. Supply Chain Management, 19983 (1), 12.

Millman, A. and Wilson, K. J. (1994). From Key account selling to key account management. Tenth Annual Conference on Industrial Marketing and Purchasing, University of Groningen, The Netherlands, September 1994.

Minahan, T. A. and Vigoroso, M. W. (2002). The Supplier Measurement Benchmarking Report. Aberdeen Group and iSource December 2002 http://www.aberdeen.com, accessed July 2004.

Morgan, J. (1998). Just how good a customer are you? Purchasing, November $19^{\text {th }} 1998,125(8), 53$.

Mouncey, P., McDonald, M. and Ryals, L.J. (2004). Key Customers: Identifying and Implementing IT solutions that add value to Key Account strategies. Cranfield School of Management: Report by the Key Account Management Best Practice Research Club.

Sharma, A. (1997). Who prefers key account management programs? An investigation of business buying behavior and buying firm characteristics. The Journal of Personnel Selling and Sales Management, Fall 199717 (4), 27-39.

Sharma, A. (2000). Do salespeople and customers understand each other? Surprising results from extant research. Journal of Selling and Major Account Management, Autumn 20003 (1), 29-39. 
Swinder, J. and Seshadri, S. (2001). The influence of purchasing strategies on performance. The Journal of Business and Industrial Marketing, 200116 (4), 294-306.

Woodburn, D. and McDonald, M. (2001). World-leading key account management: identification and development of strategic relationships. Cranfield School of Management: Report by the Key Account Management Best Practice Research Club.

www.purchasing.com/article/CA295468.html. Purchasing magazine online. 19th September 2002. Accessed 25th March 2005 from www.purchasing.com.

\section{Additional Reading}

Christopher, M and Ryals, L. J. (1999). Supply chain strategy: Its impact on shareholder value. International Journal of Logistics Management, 10 (1), 1-10.

Ellram, L.M., Zsidisin, G. A., Perrott Siferd, S. and Stanly, M. J. (2002). The impact of purchasing and supply activities on corporate success. Journal of Supply Chain Management, 38 (1), Winter, 4-17.

Maltz, A B. and Ellram, L. M. (1997). Total cost of relationship: An analytical framework for the logistics outsourcing decision. Journal of Business Logistics, 18 (1), 45-66.

Wong, A. (2002). Sustaining company performance through partnering with suppliers. The International Journal of Quality and Reliability Management, 19 (5), 567-580. 
Table 1

A model for co-monitoring of strategic relationships

\begin{tabular}{|c|c|c|c|c|}
\hline $\begin{array}{l}\text { Type of } \\
\text { relationship }\end{array}$ & $\begin{array}{l}\text { Likely } \\
\text { number of } \\
\text { relationships } \\
\text { of this type }\end{array}$ & $\begin{array}{l}\text { Needs of } \\
\text { parties to } \\
\text { relationship }\end{array}$ & $\begin{array}{l}\text { Likely } \\
\text { strategic } \\
\text { procurement } \\
\text { approach }\end{array}$ & $\begin{array}{l}\text { Measurement } \\
\text { focus }\end{array}$ \\
\hline $\begin{array}{l}\text { Integrated. } \\
\text { Boundaries } \\
\text { between the two } \\
\text { companies } \\
\text { dissolve. } \\
\text { Permanent teams } \\
\text { working on-site. } \\
\text { Sole supplier. }\end{array}$ & $\begin{array}{l}\text { Very few, if } \\
\text { any }\end{array}$ & $\begin{array}{l}\text { Realization of } \\
\text { fullest } \\
\text { potential of } \\
\text { both } \\
\text { organizations. } \\
\text { 'Create bigger } \\
\text { cake' by joint } \\
\text { initiatives and } \\
\text { risk sharing. }\end{array}$ & $\begin{array}{l}\text { Long-term } \\
\text { relationship } \\
\text { with very few } \\
\text { proved and } \\
\text { trusted } \\
\text { suppliers. } \\
\text { Single sourcing } \\
\text { for some } \\
\text { categories of } \\
\text { purchase. }\end{array}$ & $\begin{array}{l}\text { Integrated: } \\
\text { Planning, return } \\
\text { on investment. }\end{array}$ \\
\hline $\begin{array}{l}\text { Interdependent. } \\
\text { Partnership } \\
\text { relationship, } \\
\text { openness and } \\
\text { trust, shared } \\
\text { information and } \\
\text { projects. Multiple } \\
\text { co-ordinated } \\
\text { contacts } \\
\text { spanning } \\
\text { boundary. } \\
\text { Favored supplier. } \\
\text { Relationship } \\
\text { monitored. }\end{array}$ & $\begin{array}{l}\text { Few (usually } \\
\text { less than 30) }\end{array}$ & $\begin{array}{l}\text { Confidence in } \\
\text { relationship, } \\
\text { stable and high } \\
\text { evaluation by } \\
\text { both sides. } \\
\text { Low risk. }\end{array}$ & $\begin{array}{l}\text { Cooperative } \\
\text { negotiation } \\
\text { with few, } \\
\text { carefully- } \\
\text { selected } \\
\text { suppliers / } \\
\text { emerging long- } \\
\text { term } \\
\text { relationships. }\end{array}$ & $\begin{array}{l}\text { Interdependent: } \\
\text { Process } \\
\text { improvement, } \\
\text { company } \\
\text { attributes/policies, } \\
\text { relationship } \\
\text { quality }\end{array}$ \\
\hline $\begin{array}{l}\text { Co-operative. } \\
\text { Several suppliers } \\
\text { with significant } \\
\text { share of spend, } \\
\text { but none } \\
\text { dominant. } \\
\text { Multiple contacts } \\
\text { between supplier } \\
\text { and customer. }\end{array}$ & $\begin{array}{l}\text { Many (may be } \\
10 \text { s or } 00 \mathrm{~s} \text { ) }\end{array}$ & $\begin{array}{l}\text { Reduction of } \\
\text { risk, ability to } \\
\text { forecast. }\end{array}$ & $\begin{array}{l}\text { Reduce the } \\
\text { supplier base, } \\
\text { improve } \\
\text { quality of } \\
\text { interaction } \\
\text { with remaining } \\
\text { suppliers. }\end{array}$ & $\begin{array}{l}\text { Co-operative: } \\
\text { Service, } \\
\text { responsiveness, } \\
\text { technical support, } \\
\text { communications. }\end{array}$ \\
\hline $\begin{array}{l}\text { Basic. } \\
\text { Transactional } \\
\text { relationship } \\
\text { essentially } \\
\text { managed by one } \\
\text { individual on } \\
\text { each side. Price } \\
\text { and performance } \\
\text { driven, hard }\end{array}$ & $\begin{array}{l}\text { Numerous } \\
\text { (may be 00s } \\
\text { or 000s) }\end{array}$ & $\begin{array}{l}\text { Operational, } \\
\text { efficient } \\
\text { transactions. } \\
\text { Sometimes } \\
\text { cost reduction. }\end{array}$ & $\begin{array}{l}\text { Reduce the } \\
\text { supplier base. }\end{array}$ & $\begin{array}{l}\text { Basic: Price, } \\
\text { delivery, quality. }\end{array}$ \\
\hline
\end{tabular}


measures.

Source: adapted and extended from Woodburn and McDonald 2001 
Figure 1

Drivers of supplier selection

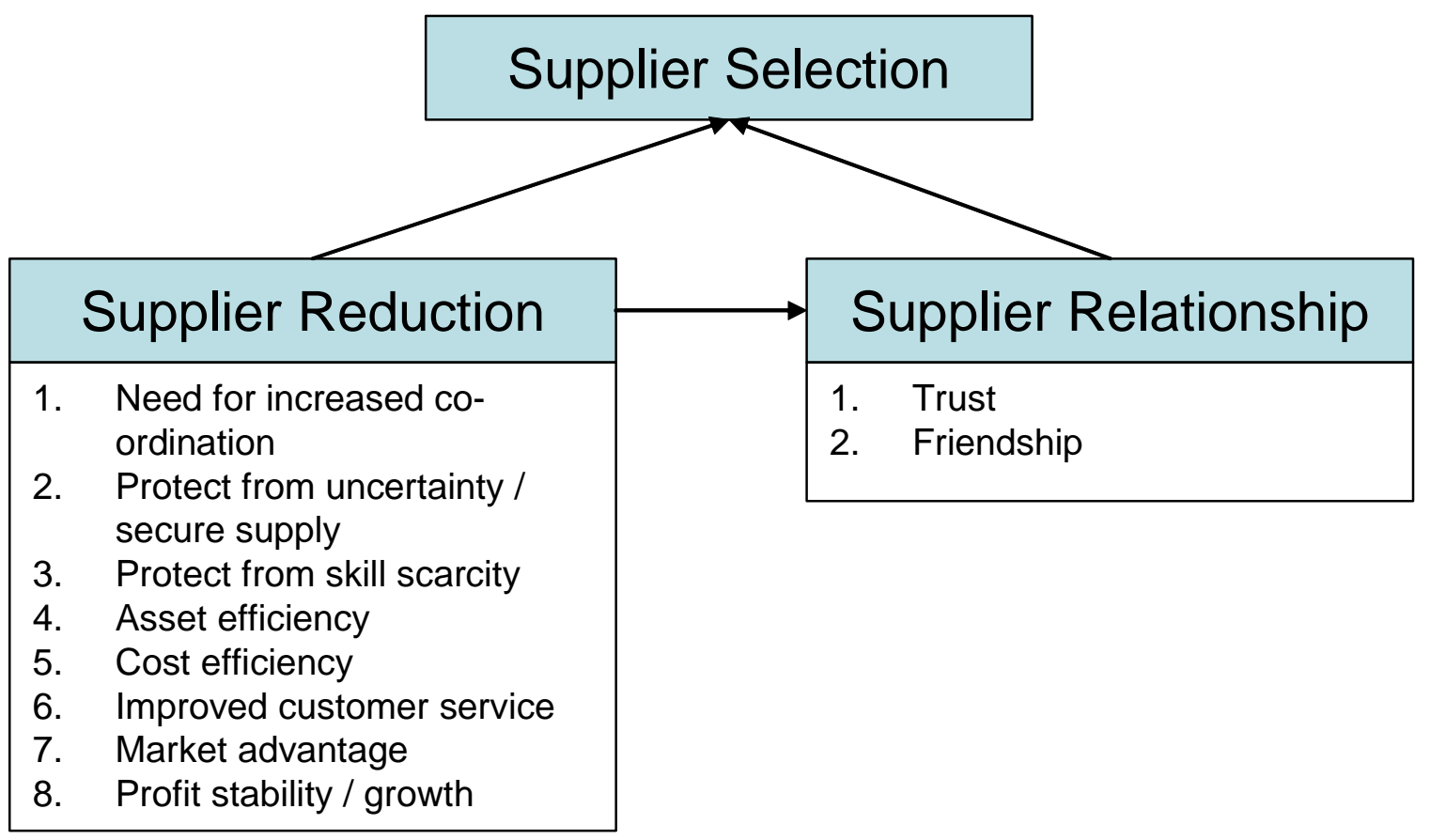

